Land Claim Negotiations and Indigenous Claimant Legibility in Canada and New Zealand

\title{
Christa Scholtz
}

Assistant Professor, Dept. of Political Science, McGill University

christa.scholtz@mcgill.ca

Paper presented to the Canadian Political Science Association Annual Meetings, May 2009, Ottawa, Ontario 


\section{Introduction}

In 1973, the Canadian federal government announced that it would commit itself to negotiating the land claims of its aboriginal peoples. The Trudeau cabinet discussed its willingness "...to negotiate with individual bands or groups, if necessary, this could be reviewed later when it could be seen how the negotiations were proceeding." ${ }^{1}$ Although the government preferred to negotiate with larger political associations in order to maximize the efficiency of negotiations, it clearly expected that Indian bands, known quantities defined under the Indian Act, would form the backbone of its negotiation policy. In the North, the fact that the Inuit were not defined under the Indian Act was not viewed at that time as an impediment to a negotiation policy, since their isolation and distinctive way of life made it relatively easy for the government to identify them. ${ }^{2}$ The Canadian government, in implementing its negotiation policy, has not worried overmuch about who would show up at the other side of the average land claim negotiation table. This stands in contrast to other negotiation contexts.

The New Zealand government announced it would negotiate with Maori in 1989, and key negotiations with the Ngai Tahu and the Tainui were soon underway. However, by 1992 cabinet recognized that its negotiation policy was encountering a serious problem, and started engaging in a policy discussion that their Canadian counterparts haven't really had. The New Zealand government had much less certainty going forward on key characteristics of their average Maori negotiating partner. Cabinet agreed that it had to establish, as a pre-condition to negotiation, that it had identified the proper claimant group, and that this claimant group had satisfied the criteria of internal structure and accountability. The key outcome of this discussion was the creation in 1994 of a new stage in the negotiation process, called the Deed of Mandate. The Deed of Mandate is in essence a group certification process, where Maori are called upon to satisfy the government's need for clarity with respect to the group's boundaries, its internal governing structure, and its authority. In Australia, a similar process has developed, in the form of state mandated Connection Reports. In these reports, state governments require aboriginal groups to set out both their membership boundaries, the internal processes and customary laws which regulate or give authoritative affect to their connection to country. Producing connection reports is an onerous process, asking aboriginal groups to prove who they are as a prelude to seeking recognition or redress of their rights.

These accounts are important because they show some key dynamics. First, that governments engaging in negotiation policies require their negotiating parties to be legible to them. James C. Scott writes that "legibility is a central problem in statecraft" (Scott 1998: 2), and this legibility issue has an important role to play in the implementation of negotiation policies with indigenous peoples. Indeed, if governments feel that there is insufficient definition or transparency to outsiders of aboriginal group boundaries and collective decision making 
structures, governments may have little confidence that agreements will either be reached or ratified. If this confidence is very low, it may dispose a government to walk away from negotiation and pursue other means of resolving a dispute, litigation being chief among these alternatives. This is demonstrated by the actions of Western Australia in the mid-1990s (Scholtz 2006: 147-152). Second, these real life accounts challenge the classical bargaining assumptions that groups come to a negotiating table fully formed, and that the composition and structure of groups are constant during the course of the negotiating process. Instead, we see that in some cases, key processes of group definition and development do not antedate the negotiation process, but are endogenous to it. The implication here is that the state, in requiring legibility, kicks off a process of formal group definition that is driven by the strict purpose of negotiating with the state. In this regard this process of group definition is not neutral, and how the group comes to define itself and its collective decision-making structures may well depart from how it would do so under different circumstances. In some ways this is neither a novel nor unexpected outcome, in so far as all identity groups are defined not only through internal processes but also through interaction with others (Monroe et al. 2000; Minow 1997; Tully 2003). However, since land claim negotiation processes concretize both aboriginal groups and rights as authoritative in the eyes of the state, the distinctive boundaries and structures of aboriginal group life that come out of these processes will have significance long after the formal negotiation process ends and all concerned get on with their lives.

There is also no guarantee that the process of aboriginal group definition that the state engenders will lead to greater clarity and with that clarity, political cohesion. Instead, political fragmentation and induced conflict may be the result. By requiring that indigenous group life be defined in order to address a land claim, the state calls upon indigenous groups to create boundaries where perhaps under customary and traditional practice these boundaries were diffuse, porous, and flexible. The very flexibility and negotiability of boundaries and collective institutions that indigenous societies may prize, either as continuations of traditional practice or as adaptations to settler colonialism, become in a state negotiation context problems to be solved or mitigated. The internal conflicts that can arise in concretizing what for other reasons have been left fluid can be serious. This internal disputation risks the delegitimization of the group in the eyes of outsiders. "You people just can't get it together", is the frustrated refrain of those on the outside looking in, seeing pathology in lieu of complexity.

In this paper I explore the legibility to the state of aboriginal claimant groups. First, I address more deeply why governments demand legibility in the context of negotiation. Second, I set out a historically embedded account of how this legibility has evolved in two cases: Canada and New Zealand. How is it that the Canadian federal government, before embarking on a negotiation policy, faced on average aboriginal claimant groups that the state felt were relatively defined? How is it that the New Zealand government did not find themselves in that 
situation, and had to modify their negotiation policy as it was implemented? To answer this question I explore the historical processes which intersected to either produce or thwart the emergence of legible indigenous groups. This is not to say that Canadian aboriginal groups are without exception defined and politically cohesive. Indeed, there is important variation within these countries (Alcantara 2007). I am interesting in exploring, if you will, a cross-national difference in means rather than standard deviations. What explains this variation across average claimant groups? To do so I identify four historical processes, or indicators: 1) the customary centralization of political authority within the traditional claimant group; 2 ) the recognition of the claimant group within the settler legal system; 3 ) the geographic or spatial definition of the claimant group through reserve land policies; and 4) the role of the claimant group in the provision of social and welfare services. I contend that it is important to understand how these processes interact to produce an average claimant group that governments, as outsiders, felt they could negotiate with once they came to the conclusion that negotiation was necessary. For each case, I explore how the issue of claimant legibility impacted the design and implementation of the respective negotiation policy.

\section{Legibility and Negotiation}

In the simplest negotiation, two unitary players negotiate on their own behalf and reach an agreement on one issue. Each player recognizes the other as being the appropriate or proper party to make a final decision about the one issue in question. In other words, each player accepts that he is dealing with whom he should, and the fundamental bona fides of each player is clear. Therefore, the decision to sit down to bargain in the first place is conditioned on basic knowledge each has about the other. Each party must be reasonably transparent -legible, or known-- to the other.

Actual negotiations depart from this simple scenario very quickly. Once players are no longer unitary but negotiate on behalf of a larger group, each player's decision to negotiate may depend in part on whether he is reasonably assured that the larger communities the negotiators represent will ratify a settlement agreement. A player's future payoff from sitting down at the bargaining table is presumably diminished if he foresees serious impediments to ratification across the table, especially as the number of issues under discussion rise. His future payoff is presumably further diminished if, during the course of a complex negotiation, he becomes unsure that the group across the table is actually the proper party to the underlying dispute. Consider an additional complication where one negotiator is sitting at not just one negotiation table, but many. It may be that by agreeing to negotiate at one table, he may commit himself to begin negotiations at other tables into the future with similar groups as the first. Because his decision to sit down at one negotiation table may involve him in other discussions he cannot yet foresee, a negotiator might want some reasonable assurances at the 
outset that he knows enough about the average type of group he may encounter. Are these groups, on average, legible? A forward-thinking government needs to be assured that on average, it will be dealing with an identifiable, appropriate, and reasonably cohesive claimant group most of the time. If it is not, settlements will not prove durable and long-term goals cannot be achieved. If the boundaries between claimant groups are extremely porous, if there is no clear collective decision-making structure, or if the government can discern that there are serious disagreements across claimants about which is the appropriate land rights-bearing entity, then government policymakers may well decide that a land claim negotiation policy has little long-term benefit. Even if such challenges do not result in pushing a government away from bargaining, they will certainly impact the negotiation process.

An important refrain in comparative political science has been the need to establish whether and how political actors, defined as social groups or the state itself, are actually able to act as strategic actors (Thelen 1999; Bates et al. 1998). How do political actors come to be? The "state-in-society" literature points out that the construction, definition, and hopefully following from that, the cohesion of any group or organization is the product of a number of struggles. It does not develop all of a piece (Migdal 1994). The struggle for group definition and cohesion is partly an internal one, where sub-groups collide and coalesce in order to build some consensus over common political goals and strategies. In political science parlance, these are struggles to define a collective identity, to accept a set of internal dispute resolution mechanisms, and to overcome collective action problems. But group definition and cohesion are a function of forces both internal and external to the group itself. A key external struggle which can both define and fragment social groups is the historical pattern of interaction with the state. Interaction with the state is an important ingredient in the formation and constitution of groups. The state's interest in shaping social groups in particular ways is often rooted in a normative agenda, and this is perhaps nowhere as evident as with indigenous peoples. A state's interest in shaping groups can also be rooted in administrative self-interest, as the state cannot deal efficiently with myriads of groups on their own terms, and therefore must simplify and homogenize social life (Scott 1998). Through myriad mechanisms the state can have a significant impact on the delineation of a group's membership, on its internal structures, and on the group's ability to act as a cohesive political entity at a bargaining table.

\section{Legibility and Aboriginal Claimants: The Indicators}

If groups do not spring from the ether fully formed, then what are the processes of interaction which create a certain kind of aboriginal group, a legible claimant that the state determines a suitable negotiation partner? I now turn to the four indicators that I introduced above. After further developing each, I will turn to historical case studies. 
Centralization is an indicator relating to the constitution of political and legal power within the customary indigenous group. The more a traditional land rights bearing group acts as a politically autonomous group within customary law, the stronger the customary basis for a cohesive and negotiating party. Also, the degree to which political authority is customarily centralized or specialized within the group, the more politically legible the group in the eyes of the state, as this centralization echoes the structures of the state itself . The most legible manifestation of political centralization is the practice of chieftainship. The practice and meaning of chieftainship varies in traditional indigenous social structure. The ideal types offered by political anthropologist Morton Fried (1967) offer a starting point. At one extreme, indigenous groups in areas of relative resource abundance and, as a result, relatively high population densities, developed highly systematized and hierarchical (usually hereditary) chieftainship structures. Although indigenous governance practices generally place a high value on consensus, chiefs of sub-groups are still responsible for regulating an array of conflicts, from basic social issues to the internal enforcement of customary land laws. Specific rights to defined territories are usually held by kinship, or clan-level groups, and chiefs at this level are responsible for negotiating inter-clan conflicts over land use. At the other extreme, Fried posited that indigenous groups in areas of limited resources were usually smaller autonomous kinship groups, or bands, who in the past harvested the land over larger traditional territories. Each band is part of a larger tribal group, but the band is traditionally considered an autonomous and land-rights bearing entity. The smaller population size calls for less political specialization and hierarchical distinctions within the band (Tennant 1990: 6). Chieftainship in these egalitarian bands was customarily less formalized (for example, not developing highly specific rules of succession), and chiefs' authority derives from the power to persuade autonomous individuals rather than to enforce compliance through formal decree.

Legal Recognition refers to whether and how indigenous political groups have been recognized by a settler state's legal system, either through incorporation or through some other statutory means. Legal recognition is important because it provides a standard framework which normalizes indigenous group life in the eyes of the state. For instance, "...actors in the non-indigenous domain...look to the corporation as a source of authority and legitimacy on indigenous matters" (Mantziaris and Martin 2000: 274). A state can choose to reinforce an aboriginal group's boundaries by reflecting those customary boundaries or structures in the law. Or, the state may choose to ignore, or fragment, those boundaries and structures by either recognizing them partially or inconsistently:

"The closer the apparent 'fit' between the [corporate] institution's processes and structures to those of the [claimant] group, the more the group itself will assimilate the institution to the group and its system of social and political relations. Through 
this process the group is likely to transpose conflicts and

processes that define its internal authority and legitimacy

relations on to the legal structure created by the formal act of incorporation". (Mantziaris and Martin 2000: 274)

In essence, recognition of indigenous groups in law also transforms them, as they adapt to operating within the settler legal system. That adaptation can lead to legible and reasonably coherent claimants in a negotiation process, or not. Changing or inconsistently applied recognition regimes as well as the incomplete incorporation of only some members of the underlying claimant group can fragment indigenous group cohesiveness.

Geographic definition is an indicator of whether or not state indigenous land policies historically reinforced the customary land rights-holding group through spatial organization. Government land policies map people to place, and this mapping is rarely neutral (Harris 2002). Government land policies can reinforce a traditional claimant group by defining it as a territorially-bounded political community. These policies can also fragment the claimant group's internal cohesiveness, for instance by mixing different indigenous communities on one reserve and by establishing indigenous populations outside of their traditional territories. Such fragmentation confuses the contemporary issue of who "really belongs" to and has customary rights to any given area. How land policies have geographically mapped indigenous people to place can thus increase contestation within and across claimant groups and decrease the ability of outsiders to make judgments about the legitimacy of competing claims.

Social service provision addresses whether the delivery of welfare state services to indigenous individuals reinforced their connection to customary communities, either by making social service benefits conditional on their traditional memberships, or by involving aboriginal claimant groups themselves in the delivery of services. The state can provide social services to indigenous individuals in many ways. It can make no distinctions between non-indigenous and indigenous citizens, either in the level of service provided or in its delivery. The state can distinguish between indigenous and non-indigenous, but remain blind to the traditional affiliations of indigenous people. Or, the state can also distinguish among indigenous individuals in the delivery of services by delegating service provision to tribally-defined indigenous organizations. Social service provision can reinforce the political relevance of the indigenous claimant group the more an indigenous person's access to government services is linked to his formal membership to a claimant community. The more involved such groups are in the administration of such benefits, the more legible the group to the state.

\section{Legibility and Aboriginal Claimant Groups: The Case Studies}

\section{Canada}


The Canadian case illustrates the following. Once the Trudeau cabinet was forced to consider a negotiation policy, the legibility of indigenous groups in Canada facilitated cabinet's choice. Simply put, the cabinet felt it had a clear idea with whom it could negotiate: defined, relatively cohesive, and politically capable indigenous communities. Although the average ability of indigenous groups to conduct negotiations and reach settlement agreements was not the reason which pushed the Canadian government to the bargaining table, the presence on average of a cohesive indigenous claimant group removed a possible impediment for a negotiation policy to go ahead. Cabinet concluded that it would negotiate with Indian bandlevel groups in such groups were unwilling to join in a larger regional table. Bands as defined under the Indian Act were deemed known quantities and to this day they form the backbone of the policy structure. The paragraphs below weave together how this came to be the case. I then return with a closer eye to the policy discussions of 1973.

I address centralization first. If one accepts the Fried typology, Canada's indigenous peoples span the range from hierarchical to egalitarian band societies. The centralized and politically differentiated societies are epitomized by the tribal groups of coastal British Columbia, such as the Nisga'a and Gitksan (see Sterritt et al. 1998). Examples of the egalitarian band societies are those making up the Blackfoot or the Plains Cree. Importantly, chieftainship was and is an established practice across Canada. The scope and nature of chiefs' power in egalitarian bands remain open questions in the anthropological literature, but one theme seems (to me) accepted-even in these more egalitarian societies, chiefs had the authority to act at minimum as interlocuteurs with outsiders for a relatively defined indigenous group (Leacock 1983). The general point I would take from the literature is that the traditional practice of chieftainship has adapted during the post-contact period, but not that chieftainship itself is a wholly foreign and imposed practice among traditionally egalitarian North American indigenous groups.

The importance of chieftainship and the centralization of political power within North American indigenous groups for the study of executive branch negotiation behaviour is twofold. The first seems elementary but is in direct contrast to the Australian case: that the landrights bearing indigenous community is reasonably synonymous with a more or less centralized and bounded socio-political leadership. The traditional land rights-bearing entity corresponds to a politically autonomous group. The second relates to the indigenous group's legibility to outsiders. Although government negotiators and policymakers have historically underestimated the degree to which indigenous chiefs traditionally operated through consensus politics, policymakers appreciate that chiefs could legitimately speak for a defined group of indigenous people over a wide range of issues, including land. 
The practice of chieftainship and the legibility of the group to the state is linked to Canada's reserve policies through the historical practice of treaty-making. Negotiating agreements with aboriginal nations has been a longstanding, though not comprehensive, historical process. After Confederation, as Canada sought to increase its footprint and pushed into the western frontier, aboriginal groups pressed Canada into addressing their rights, recognized under the Royal Proclamation, through a treaty process (Stonechild and Waiser 1997). At various places throughout the Prairies the federal government signed treaties with the appointed representatives of aboriginal bands. According to these agreements, the Canadian government would allocate to these bands reserved lands of the bands' choice. Although not all reserves were created as promised, or located without qualms where the bands demanded, Indian bands generally speaking were allocated some reserve lands within their traditional territories (St. Germain 2001: 92). Though the Canadian government would implement in the coming decades expropriation policies which would severely decrease the size of reserves, and eventually turned away from the treaty process, the government did hold to a basic principle that a given indigenous political and customary land-rights bearing group would have a reserved geographic space in which to reside. The reserve land policy would create a reasonable mapping of an indigenous political group within the area to which they held customary rights. The amalgamation of different indigenous groups on a given reserve was exceptional and was indeed resisted (Tennant 1990:70; St. Germain 2001: 94-95). Therefore, reserve communities have formed a key basis for political action for the modern recognition of indigenous land rights, partly because many reserve communities are not internally divided over the land rights that they customarily hold. Although many face important social and political challenges, reserve communities are also important geographic centres for the transmission of cultural and political identity (Lawrence 2004). All of these have increased the legibility of the claimant group to the Canadian state.

The legal recognition of aboriginal social groups, particularly as signatories to treaties, was effected through the Indian Act. Here I must tread carefully. The Indian Act scheme has extended legal recognition to aboriginal group life, but never neutrally and never without distortion. The Indian Act of 1876 was passed to provide a coherent legislative framework to manage Indian affairs and reserve lands, within an assimilationist worldview. Where previous legislation had defined the "tribe" as "including any band or other recognized community of Indians" (Gilbert 1996: 14), the 1876 Indian Act still recognized aboriginal social groups but much more exclusively by making their recognition in the legislation conditional on past interaction with the state. It defined a "band " as "any tribe, band or body of Indians who own or are interested in a reserve or in Indians lands in common,...or who share alike in the distribution of annuities or interest moneys for which the Government of Canada is responsible". ${ }^{3}$ An Indian was a male person of Indian blood who belonged to a band, was 
married to one, or a child of one. The federal government at once recognized customary indigenous social groups, all the while narrowing that recognition, and then imposing restrictions going forward on the membership boundaries of the band through the Act's enfranchisement provisions.

Additionally, the Act created the band council system. In the legislation, the reserve band council was to be composed of a chief (or chiefs) and councillors, elected by a majority of the male members of the band. The powers of the council were limited, and the power of the Minister reigned supreme, but the state put into place an officially recognized governing structure for the reserve. The 1876 Indian Act did not give legal effect to traditional structures of indigenous governance, but the degree to which bands actually chose their official councillors and chiefs through the Act's elective procedures varied. Customary procedures for the choice of chief and councillors persisted in some communities, although provisions within the Indian Act allowed the Minister to unilaterally impose the Act's elective procedures on the band. In the 1951 revision of the Act, a declaration by the Minister was required in order for band elections to come under the Indian Act (Imai 2005: 145). ${ }^{4}$ Currently, a band council can be elected according to custom codes upon recognition of that code by the Minister. This history of band governance under the Act illustrates that while the state has had a heavy hand in determining the structures and scope of aboriginal governance institutions, some bands have fought for and found space for the recognition of some forms of customary governance.

Band council governments have therefore been contested political structures, as traditionalists and the new elective political leadership struggled for internal legitimacy and control, with varying degrees of success. ${ }^{5}$ While the Indian Act created new political divisions within indigenous reserve communities, it also further defined, reshaped, and institutionalized a set of indigenous political structures which has become a regularized and recognized means of interaction between indigenous First Nations and the Canadian state.

The statutory recognition of aboriginal group life in the formalized form of the band council and the Indian Act's enfranchisement provisions helped to define an operating aboriginal political entity vis-à-vis the state, and trends in the delivery of social services during the expansion of the Canadian welfare state increased this legibility. From the 1950s to the late 1960s, the delivery and administration of social services to Indian communities became an important venue in the larger struggle for effective indigenous self-management and selfdetermination. Although an unintended consequence, federal government welfare policies served to develop on-reserve political expertise and strengthened the role of band governments as entities responsible for the distribution and delivery of social services to their membership. 
This process did not happen overnight. In 1950, Indian objections to the discretion of the Minister over band affairs led cabinet to accept the general principle "..of giving Indians more control over the management of their affairs and Indian band councils more power, consistent with efficient and sound administration". ${ }^{6}$ This began the gradual removal by cabinet of instances where the Minister could spend band monies without band consent. At the same time, the issue of the bands' role in the design and delivery of services was tangled in the federal government's interest in devolving as much as possible these responsibilities to the provinces. In the early 1960s, the federal government's fiscal projections of providing social services to Indians skyrocketed, ${ }^{7}$ and the federal government sought to avoid the inefficient duplication of welfare delivery services and looked to the provinces to extend provincial programs to reserve communities. In 1964, the federal government initiated intergovernmental discussions to develop a financing scheme to induce the provinces to deliver social services to reserve communities. ${ }^{8}$ The federal objectives were both fiscal and normative, as this scheme would further lessen the distinctions between Indians and other Canadians.

However, by 1964 the federal government realized that it was not longer politically expedient to ignore Indian bands during these intergovernmental discussions. The federal government's mechanism to allow minimal Indian consultation in the social service discussion was to develop and fund a reserve-based community development program. This program, the federal government assumed, would allow Indian band councils enough voice and therefore would secure Indian acceptance for whatever intergovernmental agreement would be reached. ${ }^{9}$ The federal government thought the community development program would also further on-reserve economic development, and therefore "...[stabilize] Indian welfare costs at provincial averages for the general population."10

The community development program provided funding for community development workers to develop and organize the reserve community. The unintended consequence of this program was to provide important organizational resources for Indian political entrepreneurs to develop an internal consensus that Indian band governments, not federal or provincial governments, should administer and develop programs for Indian people. The program also provided funds so community development workers could visit other reserve communities, thereby developing political networks which without resources had been difficult to sustain. ${ }^{11}$ Once it became clear that the program was in effect promoting and politicizing reserve opposition to the administration of Indian policy, the Indian Branch cancelled the program (Weaver 1981: 27-29). Regardless, the federal government soon had little choice but to involve bands further in the provision of welfare services. In 1965 the provincial governments refused to provide on-reserve social welfare services, and subsequently the federal government began to devolve the administration of on-reserve welfare services to the increasingly assertive band councils. While the ability of bands to manage and distribute band funds has been controversial 
in some quarters, it remains that band councils have undertaken the challenges and responsibilities of delivering social services to their communities. Through welfare state administration, band governments have become institutional mechanisms through which political goods are distributed to Indian communities. At least a century of official interaction with First Nations, through a historical process of treaty-making, imposition of the Indian Act, the delineation of communities through a reserve policy, and the delivery of social services created an average aboriginal party to the land claims negotiation process that was reasonably defined, both in terms of boundaries and collective decision-making institutions. In this respect, central assumptions of bargaining theory hold relatively well.

The Canadian case shows how a set of historical processes reinforced each other to create an important set of reasonably legible aboriginal political actors with which the federal government felt it could negotiate as it embarked on a negotiation strategy. The policy introduced in 1973 was not knocked off the policy rails by policymakers worrying about who they would negotiate with. The discussion was short and the conclusion relatively unproblematic. In June 1973, when Minister Jean Chrétien presented cabinet with his critical policy memorandum in favour of a negotiation policy, he did not clearly set out general criteria for the claimants with which the government would or would not negotiate. He did, however, present cabinet with information on the most likely claimants. The first group was band councils. Chrétien noted that one of the possible results of negotiated settlements would be to further the development of Indian band governments in the form of federal municipalities. He envisioned band governments as being able to administer all types of government services, including the administration of settlement assets:

With a proper budget, Band Councils could provide all of the services normally provided by a local government - policing, recreation, public works, education and even health and housing...Since the Chief and Council are elected, they would have to respond to the needs of their people...Community budgets could be supplemented or wholly financed by the proceeds of a settlement. In time, as the bands progressed, they could also raise their own revenues. ${ }^{12}$

Aside from unspecified claims which would be put forward by band councils, the Minister was confronted by four immediate claims: the Yukon-wide claim submitted a few months earlier by the Yukon Native Brotherhood, the province-wide claim submitted by the Union of British Columbia Chiefs in July 1972, the Nisga'a land claim relating to their territorial rights in British Columbia's Nass Valley, and the Inuit claim to the eastern Arctic (now Nunavut). In an attachment to the main memorandum to cabinet, Chrétien provided preliminary details 
on who the indigenous negotiating parties were. He concentrated on the following claimant information: the probable negotiators and the wider claimant community who would be eligible for benefits under a future settlement agreement.

For the province-wide British Columbia claim, the Union of BC Chiefs would administer a claim settlement fund; the settlement funds would be disbursed to the existing band councils on some basis which they would decide. Chrétien foresaw that the Union would determine eligibility to settlement assets on the basis of legal band membership:

It may be inferred from the submission that the Union intends only those Indian people registered as members of bands in the Province to benefit from a settlement; that is they are most likely using the legal definition of an Indian person to determine eligibility. ${ }^{13}$

For the northern claims, the band council system and the registration provisions of the Indian Act did not apply. However, Chrétien did not foresee a short-term problem for negotiating a settlement resulting from the historic lack of formal community definition in these areas, due to the continuance of relatively traditional indigenous lifestyles and group structures. The following excerpt illustrates this point with respect to the Inuit claim:

There is no legal definition of Inuit (or Eskimo) status...To date the lack of definition of Eskimo status has not caused any real problems. The isolation of the people, their distinctive way of life and their relatively small number have made it relatively easy for government to identify them...Increasing mobility amongst the Eskimo people and increasing instances of mixed marriages and of moving to Southern Canada may in the not-too-distant future result in status problems. ${ }^{14}$

While the critical June 1973 cabinet memo addressed issues of indigenous group membership and governance structures, cabinet decided that it would not approve the negotiation policy without further clarification on "additional elements of substance and strategy." ${ }^{15}$ There were five additional elements, two of which related to the indigenous claimants themselves. Cabinet required further recommendations on eligibility for compensation, and with whom the government would negotiate. Jean Chrétien and the Minister of Justice submitted a second paper to cabinet focusing on these concerns. On the eligibility issue, the Ministers recommended a series of criteria, including formal Indian status, adherence to a traditional lifestyle, degrees of aboriginal descent (blood quantum), and residence in the claim area. The application of these criteria prior to the negotiations was itself 
a matter to be clarified by indigenous negotiators. On the issue of who would negotiate for the Indians, the Ministers expressed a preference for higher-level negotiations within a larger claim area, such as the Yukon claim:

It may be that Indian tribal organization...is such that the Government will find it necessary to negotiate on a more particularized band basis...but...the approach of dealing with native groups at once should be followed...if at all possible. ${ }^{16}$

The Ministers struggled with a basic tradeoff: the efficiency gained by conducting one negotiation over a larger claim area with an aggregation of indigenous groups, versus the facility of concluding a smaller agreement with a single indigenous group. While the Ministers preferred ceteris paribus having one negotiation in place of many, they also recognized that customary Indian land rights were not held at the tribal group level. The ability to hold more comprehensive negotiations was predicated on the willingness of indigenous claimants to delegate negotiating power to regional-level indigenous political associations. The cabinet concluded that it would negotiate with band-level groups if such groups were unwilling to join in a larger regional table. ${ }^{17}$

\section{New Zealand}

The Canadian experience is not universal, and I now turn to the New Zealand case to illustrate the processes underlying the lesser degree of mean claimant legibility that one sees in this antipodean context. I first focus on understanding how this situation came to be through a historical account of the four intersecting processes I established earlier. I then illustrate how this legibility issue impacted New Zealand's claims negotiation policy. Through the Deed of Mandate process I mentioned in the introduction, the New Zealand government has engendered a process of group formalization as part and parcel of its negotiation process that has no official counterpart in the Canadian context. How was it that Maori groups were significantly less legible to the New Zealand government, to the degree that a wholesale legibility process had to be instituted? The following paragraphs will outline how traditional political centralization, reserve land policies, legal recognition and social service provision interacted to produce this outcome.

Traditional Maori and North American indigenous social and political structures resemble each other in important ways. There are levels to Maori social organization, with iwi reasonably synonymous with the North American tribal group. The hapu is the major tribal sub-grouping, and is accepted as the "primary political-economic unit of Maori customary society" (Boast et al. 1999: 39). The whanau is the extended family group. Generally, customary rights in land were held and passed down at the whanau level. This meant that "...competing 
claims of right coupled with the intricate system of overlapping and intersecting rights held by members of difference kinship groups, makes it difficult to say who 'owned' the land." (Boast et al. 1999: 39) Because a person could traditionally claim hapu membership through either matrilinear or patrilinear descent, a Maori within one whanau could hold customary land rights within one hapu's traditional territory while claiming political allegiance to another. However, hapu could regulate when an individual could actively assert their rights with additional (nondescent) criteria, such as residence, actual use of the resources, and group participation (Boast et al 1999: 34). Therefore, membership within an autonomous political community was fluid, but not infinitely elastic.

Like in North America, Maori political authority was centralized through the practice of chieftainship. Political succession was accorded through descent, primogeniture, and personal ability, although the weighting of these criteria in the succession decision varied across Maori groups. The chief did not "own" territory, but while he maintained the group's confidence, "...he had the right to make decisions about both the land and [people] living under his mana" (Boast et al 1999: 39). There was a hierarchy of chiefs, but the hapu maintained its political autonomy. Ultimately, land rights and territoriality could be and were decided through war and conquest.

Government land policies would serve paradoxically to both fragment and support traditional political structures. Maori land policies had ambivalent effects, as they partially recognized Maori customary land laws while they denied and eroded tribal authority. Unlike the North American case, Maori land policy did not focus primarily on reserved lands, but on the piecemeal alienation of land from Maori control. Maori land policies did not develop into the reservation policies of North America in that the government's Maori land policies did not, through segregation, define a Maori claimant community. Unlike North American treaties, the Treaty of Waitangi did not extinguish land rights over a larger territory in exchange for exclusive Maori rights over lands reserved for their use. Instead, the Treaty promised the Maori continued possession of their taonga (treasures), including land. However, under the terms of the Treaty, Maori lands were alienable only to the Crown. ${ }^{18}$ With pressure from land-hungry settlers mounting, the government began to legislate in the area of Maori-held land starting in 1862. Government legislation had a major goal - to bring Maori lands into the colonial land tenure system, and to break down tribal control in those areas where Maori chiefs had succeeded in slowing land alienation.

New Zealand's Maori land legislation established a policy of tenurial substitution, where Maori could exchange customary title for a Crown grant, effectively bringing Maori lands into the government's land tenure system. The newly created Native Land Court had legal jurisdiction over Maori lands, and became responsible for the investigation of customary land 
titles and the adjudicator for title disputes. From 1862 to the early 1900 s, this process of tenurial substitution had mixed effects on Maori group structures.

Firstly, individual Maori could make an application to the Court for the investigation of customary title, regardless of whether the individual had the approval of the hapu leadership. Allowing individual Maori to drag the Land Court into questions of customary land law undermined hapu and iwi attempts in the late 1800s to make determinations regarding customary land law a strictly tribal affair (O'Malley 1998). Once the Land Court became involved, it identified customary rights holders by investigating and identifying the proper hapu. However, contrary to Maori customary law, the Maori Land Court vested legal land ownership not in the hapu or whanau itself, but rather in the individuals comprising the group. In this way, the Maori land system both functionally recognized claimant groups, and eroded collective rights through the privatization or individualization of Maori land ownership. The Land Court also disregarded customary non-descent rules for succession (such as residence and rank), resulting in individual shares being divided equally among the individual's heirs, resulting in the further fragmentation of Maori land ownership (Boast et al. 1999: 72-78). The effect of this early period in Maori land was to challenge the ability of Maori hapu and iwi to act as corporate land-holding groups, and therefore to facilitate land loss.

In 1900 the government introduced Maori Land Councils, which were an effort by Maori to stem land loss and reassert some form of Maori collective control over their lands. Maori owners would be incorporated and would voluntarily vest their lands in the Land Councils, which would then be in charge of developing, leasing, or selling Maori-owned land. The Council members were to be appointed by the government and elected by the Maori landowners. The Councils stalled land alienation, and under pressure from settlers, the government in 1905 made several important changes. First, the Land Councils were renamed Land Boards, and the elective Maori members were dropped. Only three appointed members remained, only one required to be Maori (Ward 1999: 155). Maori lands were compulsorily vested in the Boards, and the Boards then controlled land use decisions. What potential the Councils held for renewed hapu control over Maori land decisions was diminished substantially and quickly. By the 1930s, almost all of the agriculturally valuable Maori land passed out of direct hapu control. In 1955 the government introduced legislation which allowed Maori owners to designate freehold land as land reserved in perpetuity for a special collective use. The legislation therefore put into one statutory framework lands which are Maori reserves. Reserved lands are comprised of land such as townships, marae, and places of special cultural significance. These reserves are therefore sites for communal observance, rather than the reservations of North America where a defined political community is geographically segregated. 
The ambivalent effects of the colony's land policies on Maori group life are also illustrated by the incorporation provisions of land legislation which existed alongside the individualization of land titles. From the 1860s, individual Maori land owners could form a corporation and manage Maori lands (subject to other provisions of legislation) as a corporate body. Nothing in the legislation forced these corporations to mirror traditional social structures. The degree to which land corporations overlay and therefore gave legal effect to existing hapu or iwi boundaries is unclear; one Maori group (Ngati Porou) is credited with using incorporation as a mechanism to maintain group control over its lands (Boast et al 1999: 90). Positive effects of legal incorporation stem from the fact that the history of Maori-state interaction has provided legal mechanisms for the recognition of traditional Maori group life - such Maori land corporations, Maori councils, and Maori land trusts. Maori claimant groups have not been systematically ignored or completely wiped out through legal means. The negative effects of legal recognition of indigenous group life stem from the inconsistent, incomplete and skewed manner in which Maori claimant groups were given effect either functionally or in the law. Prior to the establishment of a land claims negotiation policy, Maori hapu or iwi had not been incorporated directly within the law under a consistent statutory legal regime. Where Maori land owners in a land corporation may form a significant subset of a given hapu's or iwi's membership, not all members of a Maori claimant group are necessarily represented part of a land corporation. In New Zealand, the Maori groups which had been incorporated within the law were not necessarily synonymous with a politically defined or cohesive claimant community.

Within this context of mixed institutional effects on Maori groups, the opportunity for customary land-rights holders to identify and to define themselves as part of a larger claimant community arose with the creation of the Waitangi Tribunal in 1975. The Tribunal process continued the legacy of both refashioning yet fragmenting traditional groups. The Act establishing the Tribunal stated that "any Maori" could register a grievance against the Crown. The wording of the Act is anchored in its primary role at its inception as a political pressure valve, so there was little thought given to restricting Maori access to the tribunal to only defined social groups. A registered claimant could therefore range all the way from a single individual acting on his own behalf to iwi-level claims registered for the benefit of a whole traditional claimant community. The Tribunal claims register is therefore an interesting mirror on Maori group identification. With the extension in 1985 of the Tribunal's jurisdiction to hear historic claims, the Tribunal received more resources to investigate claims and to prepare the claimants for a formal inquiry. In this way, the Tribunal played a role in clarifying and defining the nature of a given claim as well as the group on whose behalf the claim was filed.

I turn now to examine how the process of social service provision intersected with these other processes to affect Maori group legibility. In the delivery of social services to indigenous 
individuals, governments can either make use of indigenous group structures, and therefore define them further, or ignore them. Group definition and legibility to outsiders are strengthened if the provision of government services to indigenous individuals is conditioned on their membership and affiliation to an indigenous tribal group. In the New Zealand case, tribal groups in the form of Maori Councils had a marginal role in local service delivery until the late 1930s, when lack of administrative support led them to "peter out" (Ward 199: 160). During the period of significant welfare-state expansion after World War Two, the government did not differentiate between Maori and non-Maori in the delivery of social services. The lack of differentiation lies in two reasons: the extension of full citizenship to Maori at the outset of the colony's history, and New Zealand's status as a unitary state.

With the development of the New Zealand welfare state, the New Zealand government did not differentiate among its citizens by allowing non-Maori access to a level of service not allowed to Maori. The precedent for equal or non-differentiated treatment of the Maori citizen was his clear identification, under article 3 or the Treaty of Waitangi, as a person sharing all the benefits and burdens of citizenship. New Zealand governments were wedded to the interrelated concepts of assimilation, monoculturalism, and undifferentiated citizenship, and this normative vision had its effect on the provision of public services:

Despite the long existence of a separate department with specific responsibilities for Maori affairs, most publicly funded services (such as education, health care, accident compensation, and income support) have usually been delivered to Maori and Pakeha in the same way (i.e. via mainstream agencies) and in accordance with the same criteria. Furthermore, many of the programs once administered by the Department of Maori Affairs were little different from those operated by mainstream departments (i.e. in terms of their policy prescriptions and funding arrangements).

(Boston et al. 1996: 144-145)

Even though the Maori department delivered some social programs, the department did not extend programs to Maori individuals on the basis of a given tribal affiliation.

The status of New Zealand as a unitary state also reinforced the trend toward undifferentiated social service delivery. The normative commitment to undifferentiated citizenship did not compete with a fiscal logic to define some citizens as the financial responsibility of one level of government versus another. As a unitary state, the New Zealand government is clearly responsible for the delivery of social services for all. In contrast to the 
Canadian case, there is no fiscal incentive for the government to distinguish Maori from nonMaori in order to off-load social service costs to another level of government.

This pattern of tribally-blind administration of government services to Maori individuals changed relatively late. During the mid 1980s, the New Zealand public sector struggled with what it meant to deliver services to a bicultural population in a context of fiscal strain. In the push to devolve the administration of services to the private sector during the 1980 s, policy makers entertained whether services to Maori should be delivered through traditional social structures, particularly iwi. Increasing the role of iwi and hapu in service delivery also had important support from Maori organizations (Boston et al. 1996: 146-147). ${ }^{19}$ Therefore, outside pressure and financial crisis led to a policy development exercise (1988-89) within the Labour cabinet on whether and how iwi themselves should be incorporated within New Zealand law, so that one statutory body would be recognized to speak for iwi across functions of government. The Labour government passed the Runanga Iwi Act 1990, providing a framework for the incorporation of the iwi itself into New Zealand law. The legislation was repealed, however, by the National Party government in 1991. This illustrates that only relatively recently have factors other than land claims issues involved the New Zealand government in defining tribally-based organizations and structures. It is unclear whether the tribal groups involved in social service delivery and the tribal groups involved in land claims negotiations overlapped in terms of their political leadership, and also unclear whether these separate areas of state activity have served to further fragment or solidify tribal groupings into one definable tribal negotiating party. This possible overlapping of legal tribal organizations may have been one factor in the Runanga Iwi Act's repeal.

In 1989, New Zealand's Labour government announced their decision to negotiate Maori claims. What role did Maori group legibility play in the Labour government's decisionmaking process? I argue that the Labour government was initially confident that claimant definition and identification under the negotiation process was a manageable task. The Labour government's decision to institute a negotiation policy was conditioned by the two imminent claims which would be the policy's precedent setters. These were the Waikato Tainui and Ngai Tahu claims. The Tainui and Ngai Tahu groups are widely recognized as each having maintained a strong tribal social base and strong leadership structure. Tribal leadership was formally represented through the Tainui Maori Trust Board and the Ngai Tahu Maori Trust Board. The Tainui were involved in ad hoc negotiations with the government prior to the announcement of the negotiation policy, ${ }^{20}$ while the Ngai Tahu pursued their claim through a Waitangi Tribunal inquiry before engaging in direct negotiations. Each leadership demonstrated their capacity to negotiate with the Crown as well as their ability to build community support for a negotiated process. A key historian with the Waitangi Tribunal writes that "...it is no accident that the two 
tribes that have carried forward a structure developed in the nineteenth century - Tainui and Ngai Tahu - were the first to achieve Treaty settlements" (Ward 1999: 161).

Beyond the Tainui and Ngai Tahu, the Labour government set one formal criteria for the negotiation of a claim which related to the claimant group itself. At the inception of the negotiation policy, the Labour government knew that it would be involved in the two pressing negotiations, and did not foresee huge difficulties in identifying proper claimants given the establishment of the Waitangi Tribunal process. In its 1990 negotiation policy statement, the Labour government held only that "...the person acting on behalf of the claimants properly represents the areas, iwi, hapu and whanau concerned in the claim" (Treaty of Waitangi Policy Unit 1990: 8). The government required assurances that the negotiators had a clear mandate to negotiate from the registered claimant group, but the government demanded no formal mandating processes at this point. ${ }^{21}$ Claimant characteristics also did not comprise one of the formal criteria the government used to prioritize its efforts across negotiations (Treaty of Waitangi Policy Unit 1990: 9).

It was in the policy implementation stage that the lesser legibility and cohesion of Maori groups came to have its primary effect. As the Canadian government twenty years before, the New Zealand government preferred to negotiate comprehensive agreements at the tribal group level, primarily in the interests of efficiency. Through negotiations already underway and through growing knowledge of the Maori political scene, the government understood the extent to which tribal ability to negotiate and deliver on the terms of a settlement agreement varied dramatically. In March of 1991, cabinet began discussing key outstanding policy issues, and central among these were issues of claimant representation. Looking to the conduct of future negotiations, cabinet heard that it needed certainty on the following items: 1 ) "...clarification that the group pursuing a particular claim does generally represent those who have the right to a claim, thereby removing the possibility of duplicate claims and continuously ongoing claims", 2) "In anticipation of achieving settlements, how will settlement agreements be ratified and by whom?", and 3) "Closely linked to the issue of ratification and claimant group representativeness is the question of achieving agreement on who will be the beneficiaries of a given settlement (individually and collectively)."22

The issues of claimant representation, ratification, and beneficiaries were of growing concern for Waitangi Tribunal as well. With "any Maori" able to file a claim on any aggregation's behalf, there was minimal vetting of those bringing forth claims. In the course of its inquiries into various claims, the Tribunal itself was being called upon to make decisions about the representativeness of claimants. At the request of the Chairperson of the Waitangi Tribunal, in 1993 the government gave the Maori Land Court jurisdiction over claimant representation issues. ${ }^{23}$ 
In order for the Court to remain an avenue of last resort to resolve claimant conflicts, and to minimize the appreciable risk of failed ratifications and cross-claims, policymakers added a formal step to the negotiation process in 1994. As a prerequisite of negotiation, the government requires all Maori claimants provide a Deed of Mandate. The Deed of Mandate has become a critical sorting mechanism which demands that a claimant seeking negotiation formally provide the following information: definition of the claimant group; description of claim(s) to be covered by negotiations; definition of boundaries; mandated representatives; signatories; and confirmation of the Deed's validity (Office of Treaty Settlements 1994: 35-37).

The Deed of Mandate process is effectively a mechanism for the formal definition of the indigenous group in order to facilitate the negotiation process. The Deed of Mandate requires Maori claimants to establish publicly, prior to formal negotiation, fundamental group characteristics such as boundary definition (membership, affiliation, and territory, sub-groups) and leadership structures (representatives, corporate structure, and mandating processes). Once the government accepts the Deed of Mandate, the negotiation of the actual claim begins. Also, once a tentative agreement is reached, the government demands clarification on how the claimant will ratify the agreement, as well as clarification on how the corporation vested with the settlements' assets will relate to the larger claimant group. Therefore, the government also furthers the definition of the indigenous corporate group by forcing the claimant group to clarify its own self-governance regime (ie. terms for ratification and internal conflict resolution). Groups have varied in the length of time it takes to meet the Deed's conditions. In the Taranaki region, a claimant group took less than a year to fulfill the Deed's conditions. ${ }^{24}$ In the Muriwhenua land claim of the North Island, the Te Rarawa claimant group received its Deed of Mandate in March 2002 after approximately seven years of meetings. ${ }^{25}$

\section{Conclusion}

The historical approach I adopt here problematizes some basic assumptions of the simplest bargaining scenario: that prior to bargaining's debut, each party is legible to each other; each party accepts the other as the proper party to the underlying dispute; and that such basic properties of each party do not change during the course of negotiation. I use a particular kind of case to illustrate how simple such assumptions are. I present the role of indigenous group legibility on government land claim policy choices. Focusing on Canada and New Zealand, I show how indigenous socio-political structures and their interaction with the state constructed a less or more legible average claimant group prior to the onset of negotiations. I also show how this legibility is important in the implementation of a claims negotiation policy, and can even be endogenous to it. I have identified four historical processes which have impacted on claimant legibility, although it is more accurate to think of land claim negotiations as a newer, but vitally important, fifth process. 
This paper confirms the larger conclusion that institutions and policy choices cannot be understood outside of the socio-political context in which these institutional choices are embedded. Here I add another dimension to the process of indigenous group construction and its impact on policy. I focus on indigenous group construction, but not on the construction of a pan-Indian or pan-Maori political community. While pan-tribal groups push governments to recognize land rights, the land rights-bearing indigenous entity usually is not a national or even regional one, but more often local. The New Zealand Maori Council pushed the New Zealand government to negotiate Maori land rights, but the Tainui, the Ngai Tahu, and Ngati Ruanui are the claimants at the negotiation table. In Canada, the Indian Association of Alberta was important in fighting off Trudeau's White Paper, but Canadian governments negotiate with rights-bearing groups such as the Loon Lake First Nation, the Gwichin, and the James Bay Cree. How the state understands these groups as negotiating parties, and how those groups come to be constructed, is a critically important part of state-aboriginal relations. 


\section{BIBLIOGRAPHY}

Alcantara, Christopher. 2007. “Explaining Aboriginal Treaty Negotiation Outcomes in Canada: The Cases of the Inuit and Innu in Labrador", Canadian Journal of Political Science 40: 185-207

Bates, Robert H., Avner Greif, Margaret Levi, Jean-Laurent Rosenthal, Barry R. Weingast. 1998. Analytic Narratives. Princeton, N.J.: Princeton University Press

Boast, Richard, Andrew Erueti, Doug McPhail, and Norman F. Smith. 1999. Maori Land Law. Wellington, New Zealand: Butterworths of New Zealand Ltd

Boston, Jonathan, John Martin, June Pallot, Pat Walsh. 1996. Public Management: The New Zealand Model. Auckland: Oxford University Press

Fried, Morton. 1967. The Evolution of Political Society. New York: Random House

Gilbert, Larry. 1996. Entitlement to Indian Status and Membership Codes in Canada. Toronto: Carswell

Graham, Douglas. 1997. Trick or Treaty?. Wellington, New Zealand: Institute of Policy Studies, Victoria University of Wellington

Harris, Cole. 2002. Making Native Space: Colonialism, Resistance, and Reserves in British Columbia. Vancouver: UBC Press

Imai, Shin. 2005. The 2006 Annotated Indian Act and Aboriginal Constitutional Provisions. Toronto: Thomson Carswell

Lawrence, Bonita. 2004. "Real" Indians and Others: Mixed-Blood Urban Native People and Indigenous Nationhood. Lincoln and London: University of Nebraska Press

Leacock, Eleanor. 1983. "Ethnohistorical Investigation of Egalitarian Politics in Eastern North America," in The Development of Political Organization in Native North America (1979 Proceedings of the American Ethnological Society), ed. Elisabeth Tooker, Washington, D.C.: The American Ethnological Society

McFarlane, Peter. 1993. Brotherhood to Nationhood: George Manuel and the Making of the Modern Indian Movement. Toronto: Between the Lines

Mantziaris, Christos and David F. Martin. 2000. Native Title Corporations: A Legal and Anthropological Analysis. Annandale, NSW: Federation Press in cooperation with National Native Title Tribunal (Perth WA) 
Migdal, Joel S. 1994. "The State in Society: An Approach to Struggles for Domination," in State Power and Social Forces: Domination and Transformation in the Third World, ed. Joel S. Migdal, Atul Kohli, and Vivien Shue. New York: Cambridge University Press, 7-36

Minow, Martha. 1997. Not Only for Myself: Identity, Politics and the Law. New York: The New Press

Monroe, Kristen Renwick, James Hankin, and Renée Bukovchik Van Vechten. 2000. "The Psychological Foundations of Identity Politics". Annual Review of Political Science. vol. 3: 419-447

O'Malley, Vincent. 1998. Agents of Autonomy: Maori Committees in the Nineteenth Century. Wellington, New Zealand: Huia Publishers

Office of Treaty Settlements. 1994. Crown Proposals for the Settlement of Treaty of Waitangi Claims: Detailed Proposals. Wellington, New Zealand: Office of Treaty Settlements, Department of Justice, Government of New Zealand

Scholtz, Christa. 2006. Negotiating Claims: The Emergence of Land Claim Negotiation Policies in Australia, Canada, New Zealand, and the United States. New York: Routledge

Scott, James C. 1998. Seeing Like a State: How Certain Schemes to Improve the Human Condition Have Failed. New Haven: Yale University Press

Sterritt, Neil, Susan Marsden, Robert Galois, Peter R. Grant, and Richard Overstall. 1998. Tribal Boundaries in the Nass Watershed. Vancouver: UBC Press

St. Germain, Jill. 2001. Indian Treaty-Making Policy in the United States and Canada, 1867-1877. Lincoln and London: University of Nebraska Press

Stonechild, Blair and Bill Waiser. 1997. Loyal till Death: Indians and the North-West Rebellion. Calgary: Fifth House Ltd

Tennant, Paul. 1990. Aboriginal Peoples and Politics: The Indian Land Question in British Columbia, 1849-1989. Vancouver: UBC Press

Thelen, Kathleen. 1999. "Historical Institutionalism in Comparative Politics," Annual Review of Political Science, vol. 2: 369-404

Treaty of Waitangi Policy Unit. 1990. The Direct Negotiation of Maori Claims. Wellington, New Zealand: The Treaty of Waitangi Policy Unit, Department of Justice, Government of New Zealand 
Tully, James. 2003. "Identity Politics", in Terence Ball and Richard Bellamy (eds.), The Cambridge History of Twentieth-Century Political Thought. New York: Cambridge University Press. 517-533

van Meijl, Toon. 1997. "The Reemergence of Maori Chiefs: "Devolution" as a Strategy to Maintain Tribal Authority," in Chiefs Today: Traditional Pacific Leadership and the Postcolonial State, ed. Geoffrey M. White and Lamont Lindstrom. Stanford: Stanford University Press. 84-107

Ward, Alan. 1999. An Unsettled History: Treaty Claims in New Zealand Today. Wellington, NZ: Bridget Williams Books

Weaver, Sally M. 1981. Making Canadian Indian Policy: The Hidden Agenda 1968-1970. Toronto: University of Toronto Press

${ }^{1}$ Cabinet minutes, serial 32-73, July 19, 1973

${ }^{2}$ Cabinet document 570-73, "Indian and Inuit Claims Policy", June 6, 1973

${ }^{3}$ The 1876 also defines an "irregular band" as any tribe, band, or body of persons of Indian blood who own no interest in any reserve or lands of which the legal title is vested in the Crown, who possess no common fund managed by the Government of Canada, or who have not had any treaty relations with the Crown". However, the Act defines an Indian under the Act as belonging to a "band", not an "irregular" one.

${ }^{4}$ In the series of proposals to revise the Indian Act brought to cabinet in 1950, the Minister responsible for Indian Affairs suggested that the Act be amended so that band councils chosen according to band custom be accepted as official bands under the Act. The reasoning given for the proposal is: “...This change is necessary in order to continue present practice with respect to Indian bands to whom the elective provisions have not been applied. With few exceptions the Indian bands of the Prairie Provinces, Territories, and British Columbia are in this category. These bands choose chiefs and councilors according to varying band customs...It may be mentioned that some bands have a tribal system of organization which serves their needs effectively and which they would be very reluctant to have changed." NAC, RG2 series B2, vol.137, file C-20-5. Cabinet document 284-50, "Proposed Changes in Bill 267 (An Act respecting Indians)", December 13, 1950

${ }^{5}$ I have seen no systematic empirical analysis of the extent to which Indian Act band councils have been internally legitimated, or the degree to which traditionalist versus elective cleavages drive reserve politics. The existence of such a cleavage is clear, but its parameters are not.

${ }^{6}$ National Archives of Canada (hereafter NAC), RG2 series B2, vol.137, file C-20-5. Cabinet document 278-50, "Proposed Changes in Bill 267 (An Act respecting Indians)", December 5, 1950

${ }^{7}$ In 1964, Cabinet was advised that "...Indian dependency is $36 \%$ as against the non-Indian average of 3.5\%." NAC, RG2, vol.6259, file 139-64, memorandum to cabinet 139/64, March 19, 1964

${ }^{8}$ One federal proposal read as such: "The Indian...is a 'high cost' beneficiary of welfare programs. It is reasonable that the entire additional costs resulting from these differences be assumed as a federal responsibility. Therefore under the proposed formula the federal government would pay $100 \%$ of these costs. In turn the provinces would assume the balance of the cost of providing welfare services to its Indian residents to the same level as provided to other residents". NAC, RG2, series B2, vol.6260, cabinet document 221/64, May 19, 1964

9 " [Indians] could be expected to resist the prospect of a general extension of provincial programs...In some areas...there could be a diminution of standards if provinces entered these fields. Indians are conscious of this and associate activities in these areas with treaty rights. On the other hand, through effective consultation it will be possible to secure their support to the function-by-function [extension of provincial services] in areas where provinces have special competence". NAC, RG2, vol.6260, cabinet document 204/64, "Memorandum to Cabinet on Social Security and Labour: Extension of Provincial Services to Indians", May 8, 1964 
${ }^{10}$ NAC, RG2, Series B2, vol.6260. Cabinet document 139/64," Memorandum to Cabinet: General assistance and welfare service programmes for Indians", March 19, 1964

${ }^{11}$ For George Manuel's experience in the community development program see McFarlane (1993),

${ }^{12}$ Cabinet document 570-73, "Indian and Inuit Claims Policy/Politique concernant les revendications des indiens et des inuits", June 5, 1973, p.9

${ }^{13}$ Cabinet document 570-73, Attachment C, p.1

${ }^{14}$ Cabinet document 570-73, Attachment C, p.3

${ }^{15}$ Cabinet conclusion, meeting 25-73, June 14, 1973

${ }^{16}$ Cabinet document 667-73, "Indian and Inuit Title and Claims / Titres et réclamations des Indiens et Inuit «, June 27, 1973, p.5

${ }^{17}$ Cabinet conclusion, meeting 32-73, July 19, 1973

${ }^{18}$ The Crown waived its right of pre-emption from the early 1860 s to the late 1890 s. During this period Maori could sell or lease their lands directly to settlers.

${ }^{19}$ Van Meijl (1997) explores how tribal organizations supported devolution as a way of cementing their own authority structures to the detriment of pan-Maori organizations.

${ }^{20}$ The negotiations broke down prior to the 1990 elections (Graham 1997: 49).

${ }^{21}$ In June of 1990, the Department of Justice was formally involved in five iwi or multi-iwi claims: Ngati Te Ata (WAI 31), the Tainui Maori Trust Board (WAI 30), Ngati Te Wai/Ngati Ranginui (WAI 42 and 47), and the Maori forests claim. The government also expected to be involved quite quickly in three other claims. (Cabinet document TOW (90) 13, June 26, 1990)

22 Cabinet document TOW (91) 4, Structures for the resolution of Treaty of Waitangi Grievances, March 11, 1991. Underlining in the original.

${ }^{23}$ Section 30 of the Te Ture Whenua Maori Act 1993 holds that the Maori Land Court can "at the request of the Chief Executive or the Chief Judge, determine in relation to any negotiations, consultations, allocation of funding or other matter, the persons who, for the purpose of the negotiations, consultations, allocation of funding, or other matter, are the most appropriate representatives of any class or group of Maori affected by the negotiations, consultations, allocation or other matter".

${ }^{24}$ Interview, Office of Treaty Settlements, Wellington NZ, April 10, 2001

${ }^{25}$ Te Rarawa is one of the claimant groups of the Muriwhenua land claim lodged with the Waitangi Tribunal in December 1987. In 1995, Te Rarawa repealed its negotiating mandate from the Muriwhenua negotiators. From 1995 to 2001, Te Rarawa sought its own mandate to negotiate as a separate entity. The Crown recognized the Te Rarawa mandate in March 2002. 